\title{
Landscape Reconstruction Using Analogues at Ranger Mine, Northern Territory, Australia
}

\author{
I. Hollingsworth Earth Water Life Sciences Pty Ltd, Australia
}

J. Croton Water and Environment Consultants Pty Ltd, Australia

I. Odeh The University of Sydney, Australia

E. Bui University of Singapore, Singapore

D. Klessa Earth Water Life Sciences Pty Ltd, Australia

\section{INTRODUCTION}

We have developed an approach to designing a post-mining landform at Energy Resources of Australia (ERA) Ranger Uranium Mine that is based on analogues in the natural landscape so as to directly address the Environmental Requirements for closure, that is mined land should return to a condition consistent with the land use values and management of the surrounding Kakadu National Park, a World Heritage area. The Ranger Uranium Mine (RUM) is located within the $78 \mathrm{~km} 2$ Ranger Project Area (RPA), $250 \mathrm{~km}$ east of Darwin, in the Alligator Rivers Region of the Northern Territory. The land use values that the Mirarr Traditional Owners apply to the area are a key factor in the planned rehabilitation of the site. Consequently, planning for landscape reconstruction at Ranger Uranium Mine will begin with backfilling two mined-out pits with waste rock and tailings. However, the final landform and surface cover will need to be built in context with the undulating rises and savannah woodland environments in the surrounding landscape. Also, hill slope environmental processes that determine the sustainability and diversity of ecosystems in the vicinity of the mine need to be reflected in achieving revegetation success. In the seasonally monsoonal climate water balance processes operating at a hill slope scale, particularly those influencing plant available water and drainage are key factors affecting the type and vigour of native vegetation. In addition, the need to ensure that radiation health and water quality objectives can be met in the receiving environment at Ranger will be a critical issue. Consequently, the effects of revegetation and substrate on groundwater recharge and stream flow need to be investigated at the design stage.

\section{DESIGN PROCESS}

The process that we are using to produce a construction plan for the post-mining landform is outlined in Figure 1. Our approach sets a vision and clearly defined rehabilitation goals and makes use of current developments in ecological engineering for mine landscape restoration (Hancock, 2004; Hancock et al., 2003; Nicolau, 2003), drawing on the properties of stable landscapes in the vicinity of the mine (Nanson et al.,1993). This process is iterative and involves internal and external review and evaluation and application to the Minesite Technical Committee for approval to construct. Consultation points are indicated by numbered circles in Figure 1. Design elements would be revised when the mine plan is reviewed. The elements identified in the design process diagram are outlined in this paper.

\subsection{Life of Mine Plan}

Currently, the planned end of mining is in 2008 and tailings deposition in Pit 1 will be complete in 2008 . Tailings will then be transferred to the mined out Pit 3 until the milling process is finished in 2014 . Backfilling Pit 1 with waste rock is planned to start in 2016 and finish in 2017 while backfilling of Pit 3 is planned to start in 2017 and be completed in 2018. 


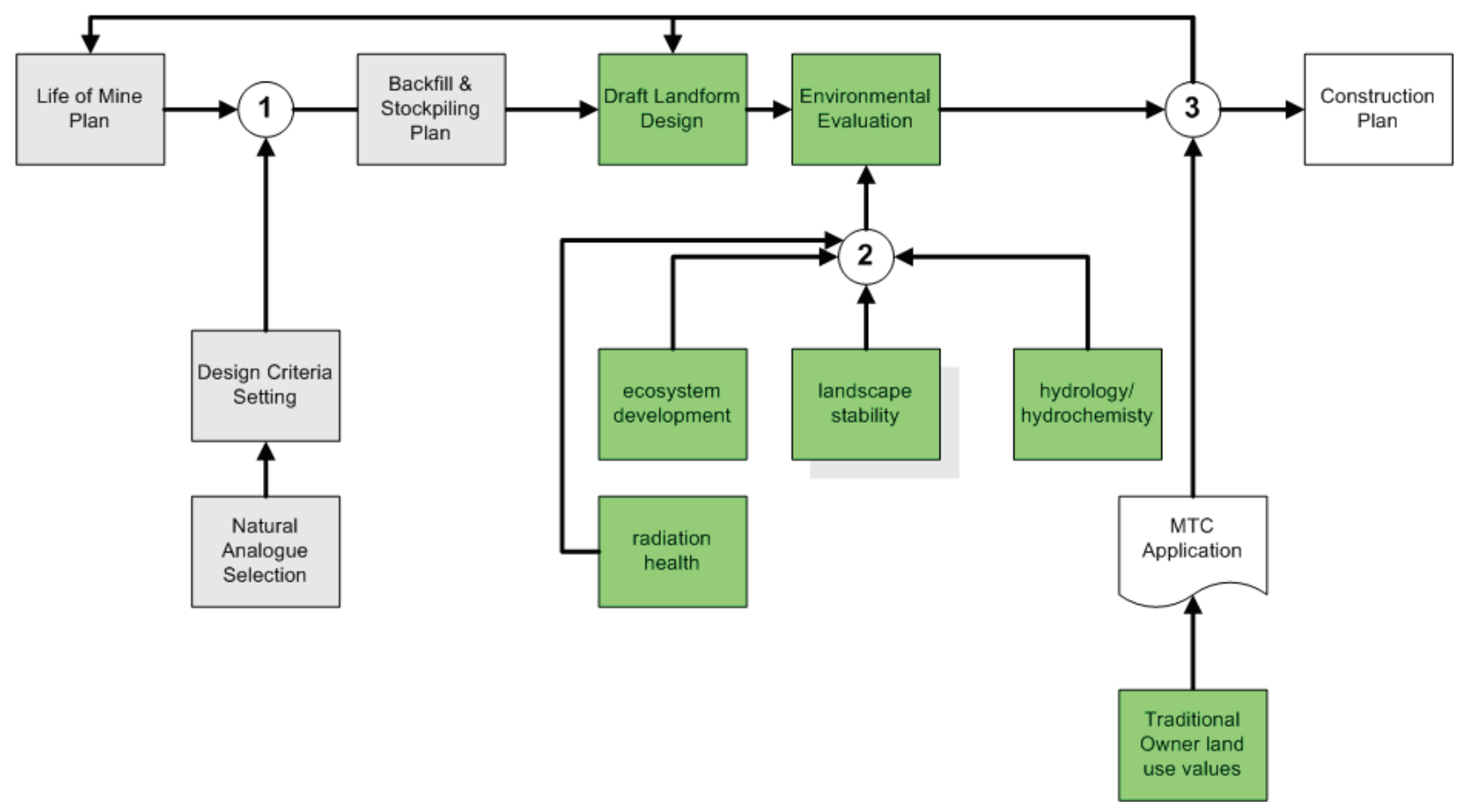

Figure 1 Design process

\subsection{Natural Analogue Selection}

Digital terrain analysis methods using raster data at an appropriate resolution are ideal for analysing the fine pattern and scale of habitat variation in the hill slope environments and software has been developed for this express purpose (Moore et al., 1993; Gallant and Wilson, 1996) and applied to a range of ecological mapping and conservation tasks (Moore et al., 1993; Mackey et al., 2000; Coops and Catling, 2002). Also, patch analysis methods have been developed to analyse landscape pattern for habitat conservation (McGarigal and Marks, 1994).

We have used digital terrain analysis to calculate a range of topographic parameters (erosion and sedimentation indices, wetness index, relief, catchment size, slope and landscape curvatures) to describe the variation in the physical environment supporting ecological diversity. We then applied these analytical tools to the landform design task at Ranger Mine (Hollingsworth and Lowry 2005). Figure 2 depicts the analogue selection process. Habitat diversity was modelled in fine detail using derived topographic parameters. Multivariate analytical techniques, commonly used in conservation ecology (McGarigal and Marks, 1994), were then used to select analogue landforms that were similar in size and habitat mix to a draft final landform for Ranger mine. 

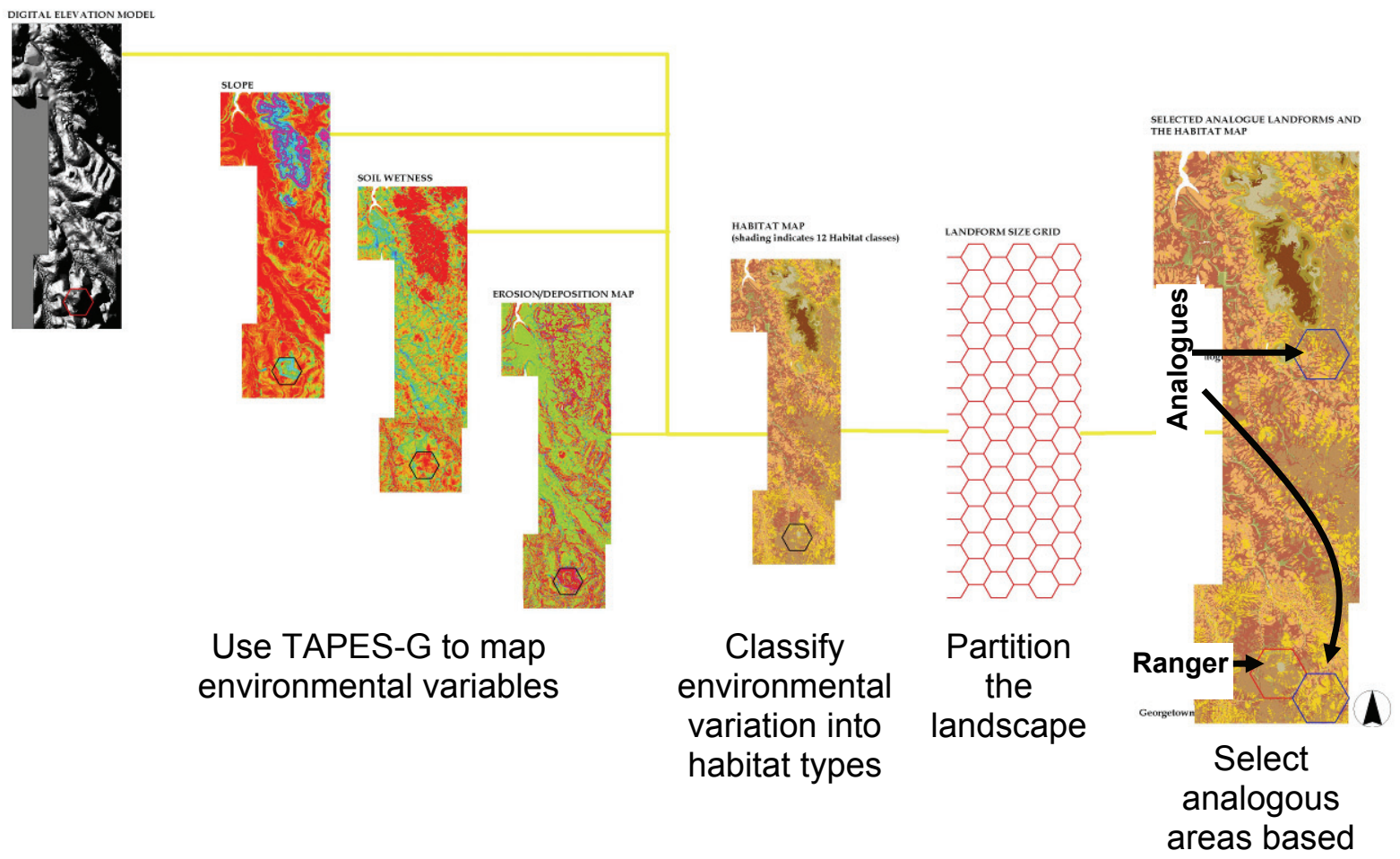

Figure 2 Analogue selection process

\subsection{Design Criteria}

Landscape design criteria were determined from a digital terrain model of natural analogue areas with the aim of producing a landform design that demonstrated similar indices of erosion and runoff distribution to the natural landscape. As a result, measured ranges of quantitative topographic attributes in the analogue landscape were used to determine the criteria (Table 1).

\section{Table $1 \quad$ Landform design criteria}

\begin{tabular}{|c|c|c|}
\hline Attribute & Units & Range \\
\hline Top slope $(\%)$ & $\%$ & $0-6.5$ \\
\hline $\operatorname{Relief}(\mathrm{m})^{1}$ & $\mathrm{~m}$ & $<35$ \\
\hline Profile curvature $^{2}$ & Radius (m) & -5000 (concave) to 5000 (convex) \\
\hline Plan curvature $^{3}$ & Radius (m) & -100 (vale) to 100 (ridge) \\
\hline Flow length (m) & $\mathrm{m}$ & $<170 \mathrm{~m}$ \\
\hline Catchment area & $\mathrm{m}^{2}$ & $<10$ ha in hillslope environments \\
\hline Batter slope & $\%$ & $20-33$ \\
\hline Drainage & & $\begin{array}{l}\text { Water shedding (open drainage) and } \\
\text { integrated with existing catchments }\end{array}$ \\
\hline
\end{tabular}


The natural soils in analogue areas are massive and earthy, gravelly, sandy loams at the surface to sandy clay loams at depth. The cover will represent this to an extent, being constructed from a well graded mix of primary and weathered Material 1's. A bridging structure of primary rock will confer erosion resistance while an infilled matrix of weathered material will confer water holding properties and enhanced control of radon emanation. Cover design criteria are listed in Table 2.

To ensure the long term sustainability of savannah woodland similar in density and abundance to the natural ecosystems at Ranger, environmental support provided by a waste rock cover will need to provide for plant available water store in the surface $5 \mathrm{~m}$ similar to that available in local woodland environments. According to Cook (1998) this amounts to 400-500 mm deficit at the end of the dry season. While the surface $2 \mathrm{~m}$ contains most of the root activity, deeper profile water retention is likely to be critical to tree survival in periods of extreme drought. This can be achieved using a well graded mixture of primary and weathered rock.

The outer cover layer of the landform will need to restrict radon emanation and gamma radiation emissions to levels consistent with guidelines current at the time of closure. Research to date indicates that a $0.5 \mathrm{~m}$ thick layer of 1 grade $\left(<200 \mathrm{mg} / \mathrm{kg} \mathrm{U}_{3} \mathrm{O}_{8}\right)$ waste will achieve this objective. The concurrent requirement for erosion protection will require that the layer be somewhat greater than $0.5 \mathrm{~m}$ thick to accommodate erosive losses over the long term.

\section{Table 2 Cover design criteria}

\begin{tabular}{|c|c|c|}
\hline Attribute & Units & Range \\
\hline Environmental health -radon barrier & $\mathrm{m}$ & $>0.5$ clean waste material (Material 1's) \\
\hline Environmental health $-\left[\mathrm{U}_{3} \mathrm{O}_{8}\right]$ & mg.kg ${ }^{-1}$ & $<200$ \\
\hline $\begin{array}{l}\text { Environmental health - Containment of } \\
\text { mineralised material }\end{array}$ & years & $>1000$ \\
\hline Erosion and sediment control & & $\begin{array}{l}\text { Graded banks will be designed and installed on } \\
\text { slopes to cope with 1:200 yr recurrence } \\
\text { interval storm events, } \\
\text { sediment basins and wetlands will control all } \\
\text { drainage leaving the waste rock landform }\end{array}$ \\
\hline $\begin{array}{l}\text { Environmental health - } \\
\text { erosion protection }\end{array}$ & $\%$ cover & $>50$, rock or vegetation cover \\
\hline Environmental health - erosion protection & $\mathrm{m}$ & $\begin{array}{c}3.0<5.0 \mathrm{~m} \text { thickness of low ARD risk material } \\
\text { comprised of a bridging structure of primary rock }\end{array}$ \\
\hline $\begin{array}{c}\text { Ecosystem support - root growth medium \& } \\
\text { infiltration control }\end{array}$ & $\mathrm{m}$ & $\begin{array}{l}3.0<5.0 \mathrm{~m} \text { thickness of low ARD risk material } \\
\text { comprised of a matrix of weather rock material }\end{array}$ \\
\hline Ecosystem support- Drainage - surface slope & $\%$ & $0.2-6.5$ \\
\hline $\begin{array}{c}\text { Ecosystem support - Top surface treatment }{ }^{\mathrm{b}-} \\
- \text { seedbed }\end{array}$ & $\mathrm{m}$ & Contour ripping to 0.5 \\
\hline $\begin{array}{r}\text { Ecosystem support - } \\
\text { prop }\end{array}$ & $\%$ & $\begin{array}{c}-30-50 \%, \text { weathered and primary waste rock well } \\
\text { graded mixture }\end{array}$ \\
\hline $\begin{array}{l}\text { Ecosystem support - Capping water balance } \\
\text { Ecosystem support - Capping water balance } \\
\text { Plant Available Water Capacity }\end{array}$ & $\mathrm{mm} \cdot \mathrm{m}^{-1}$ & Similar seasonal range to natural analogue \\
\hline $\begin{array}{c}\text { Ecosystem support - Capping water balance } \\
\text { Ecosystem support - Capping water balance } \\
\text { Drainage }\end{array}$ & $\mathrm{m}$ & Similar seasonal range and duration of water table \\
\hline $\begin{array}{l}\text { Ecosystem support - Soil fertility (pH, EC, } \\
\text { available N, P, K, organic carbon) }\end{array}$ & - & $\begin{array}{l}\text { Similar seasonal range in indicator values to the } 0 \\
\text { to } 0.2 \mathrm{~m} \text { zone in natural analogues }\end{array}$ \\
\hline $\begin{array}{c}\text { Ecosystem support - Landscape function } \\
\text { analysis }\end{array}$ & - & $\begin{array}{c}\text { Similar seasonal range in indicator values to } \\
\text { natural analogue }\end{array}$ \\
\hline
\end{tabular}

${ }^{a}$ uniaxial compressive strength greater than $100 \mathrm{MPa}$

${ }^{\mathrm{b}}$ timed to coincide with planting \& sowing at the start of the wet season to ensure the maximum growing season for plant establishment 


\subsection{Backfill and Stockpiling Plan}

Mined rock (primary rock and weathered zone material or laterite) is radiometrically sorted into stockpile grades based on the estimated content of $\mathrm{U}_{3} \mathrm{O}_{8}$ (Table 2). Figure 3 shows the extent of the stockpiles and mined out pits at the end of mining in 2008.

Table $3 \quad$ Stockpile grading

\begin{tabular}{ccc}
\hline $\begin{array}{c}\text { Stockpile } \\
\text { Grade }\end{array}$ & $\begin{array}{c}\text { Grade Range } \\
\left(\% \mathrm{U}_{3} \mathrm{O}_{8}\right)\end{array}$ & Material Type \\
\hline 1 & $0.00-0.02$ & Clean rock \\
2 & $0.02-0.05$ & $\begin{array}{c}\text { Very low grade } \\
\text { (VLG) } \\
\end{array}$ \\
3 & $0.05-0.12$ & Low grade (LG) \\
4 & $0.12-0.20$ & Ore \\
5 & $0.20-0.35$ & Ore \\
6 & $0.35-0.50$ & Ore \\
7 & $>0.50$ & Ore \\
\hline
\end{tabular}

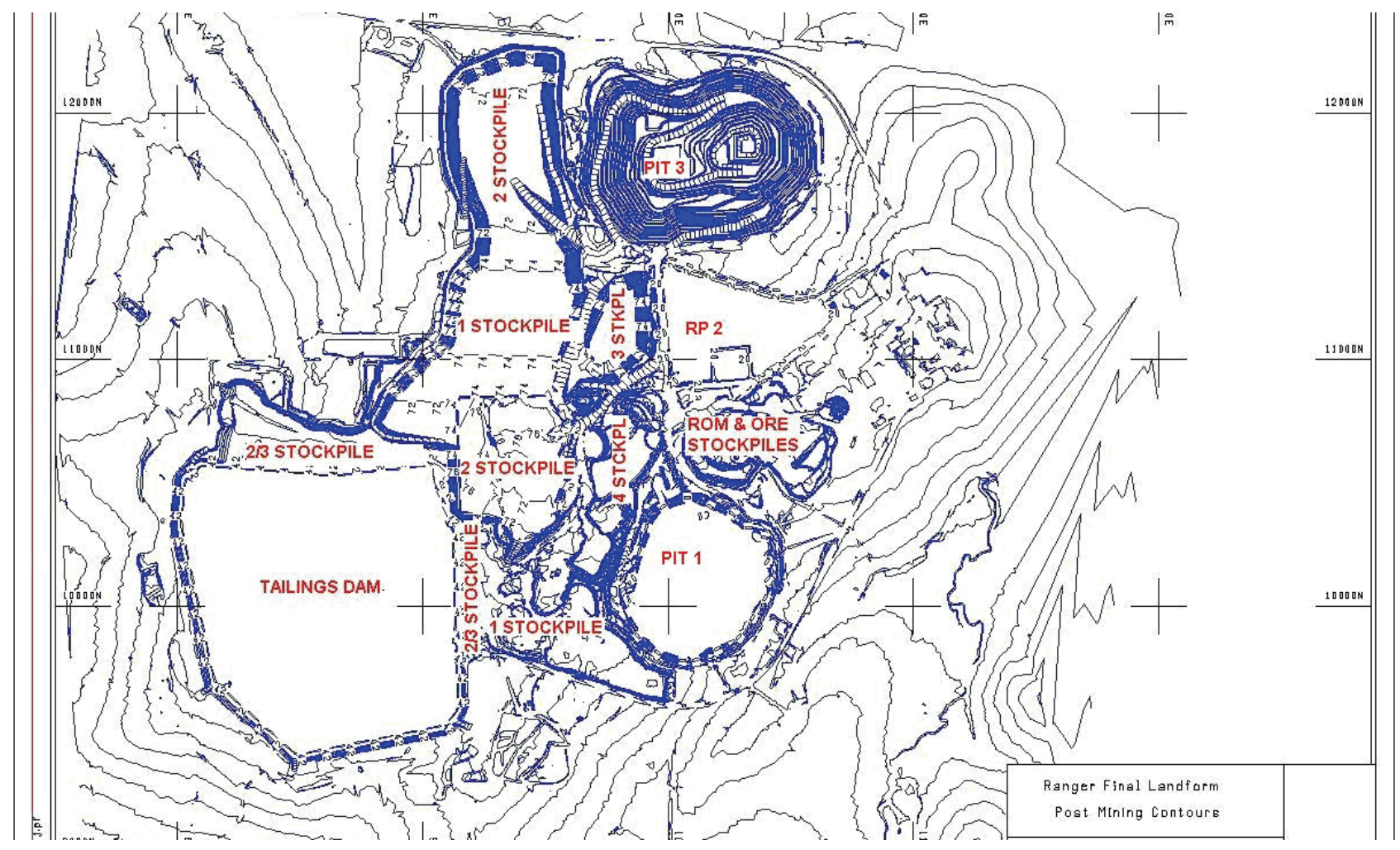

Figure 3 Stockpiling plan at the end of mining in 2008 
The backfill plan for Pit 1 is shown in cross section in Figure 4 and the backfill plan for Pit 3 is depicted in Figure 5. Mineralised waste has been placed deepest in the pits, in the zone of zero hydraulic potential and covered with clean waste rock. This reduces the potential seepage impact from mineralised material.

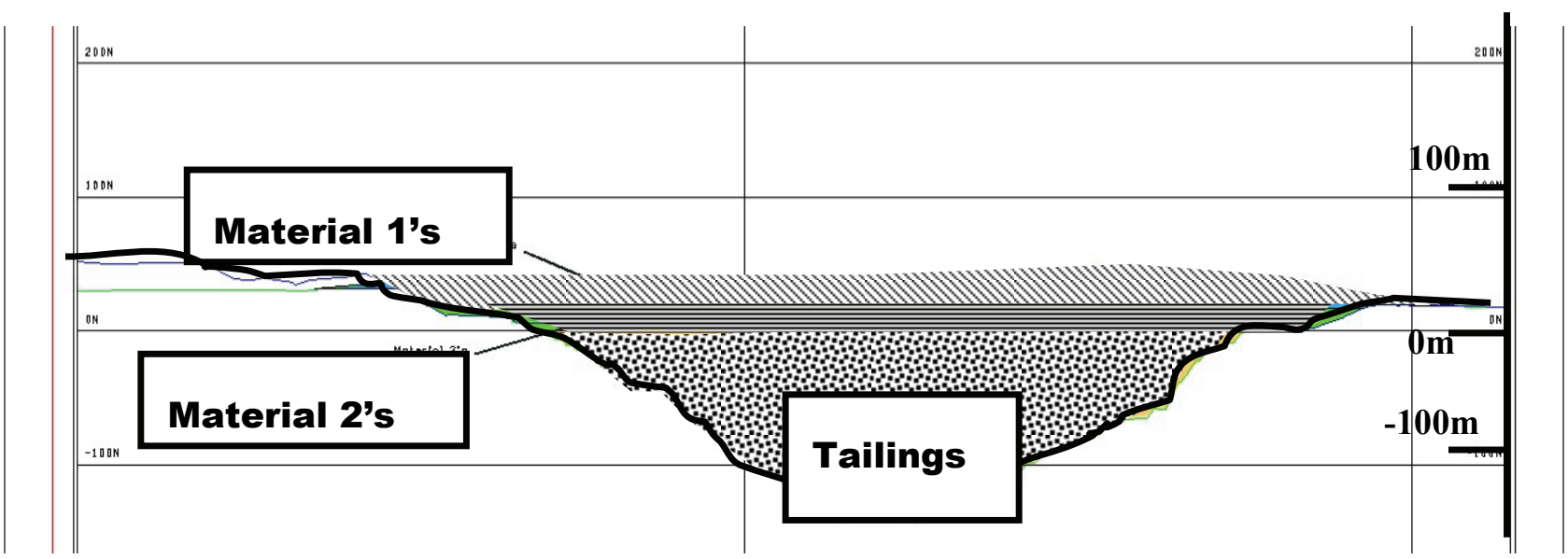

\section{Figure 4 Backfill plan for pit 1}

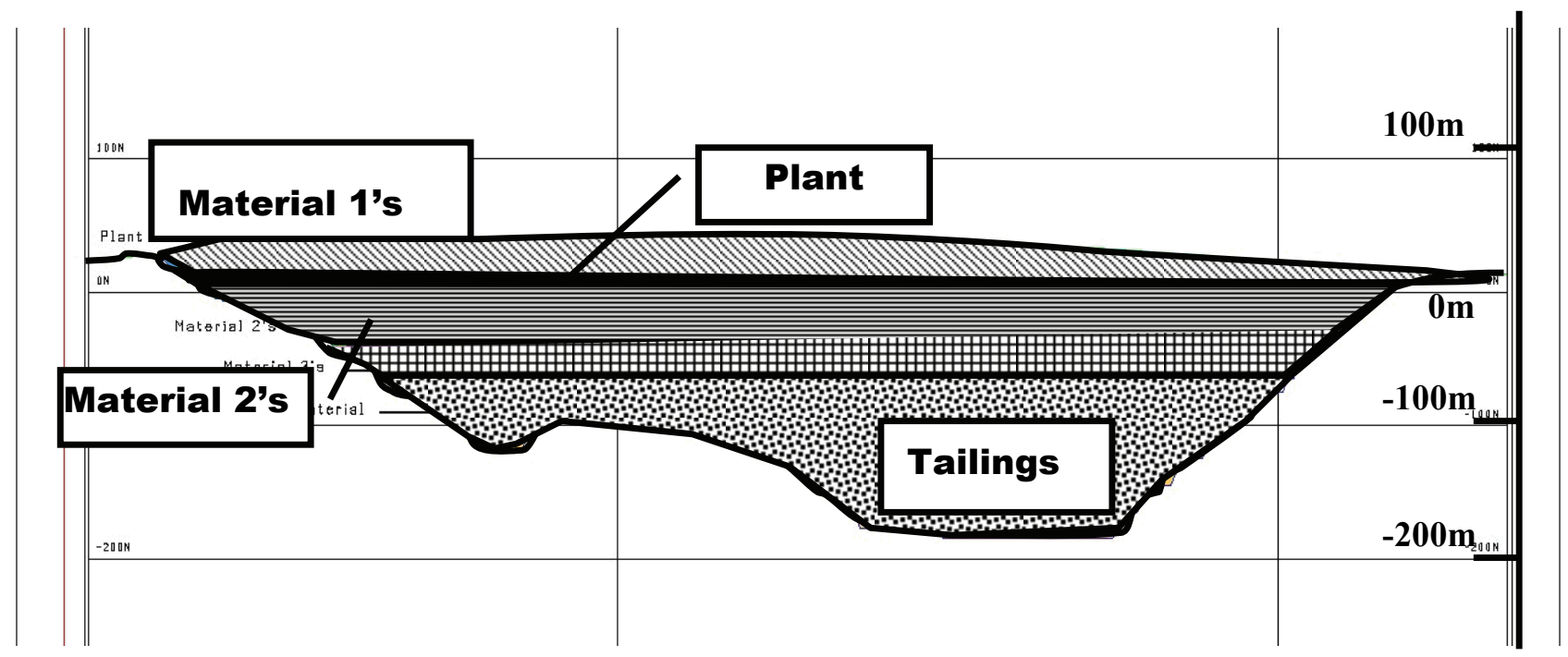

Figure $5 \quad$ Backfill plan for pit 3

\subsection{Draft Landform Design}

The draft landform design described from $2 \mathrm{~m}$ contours comprises backfilled pits and reshaped 1's stockpiles (Figure 6). 


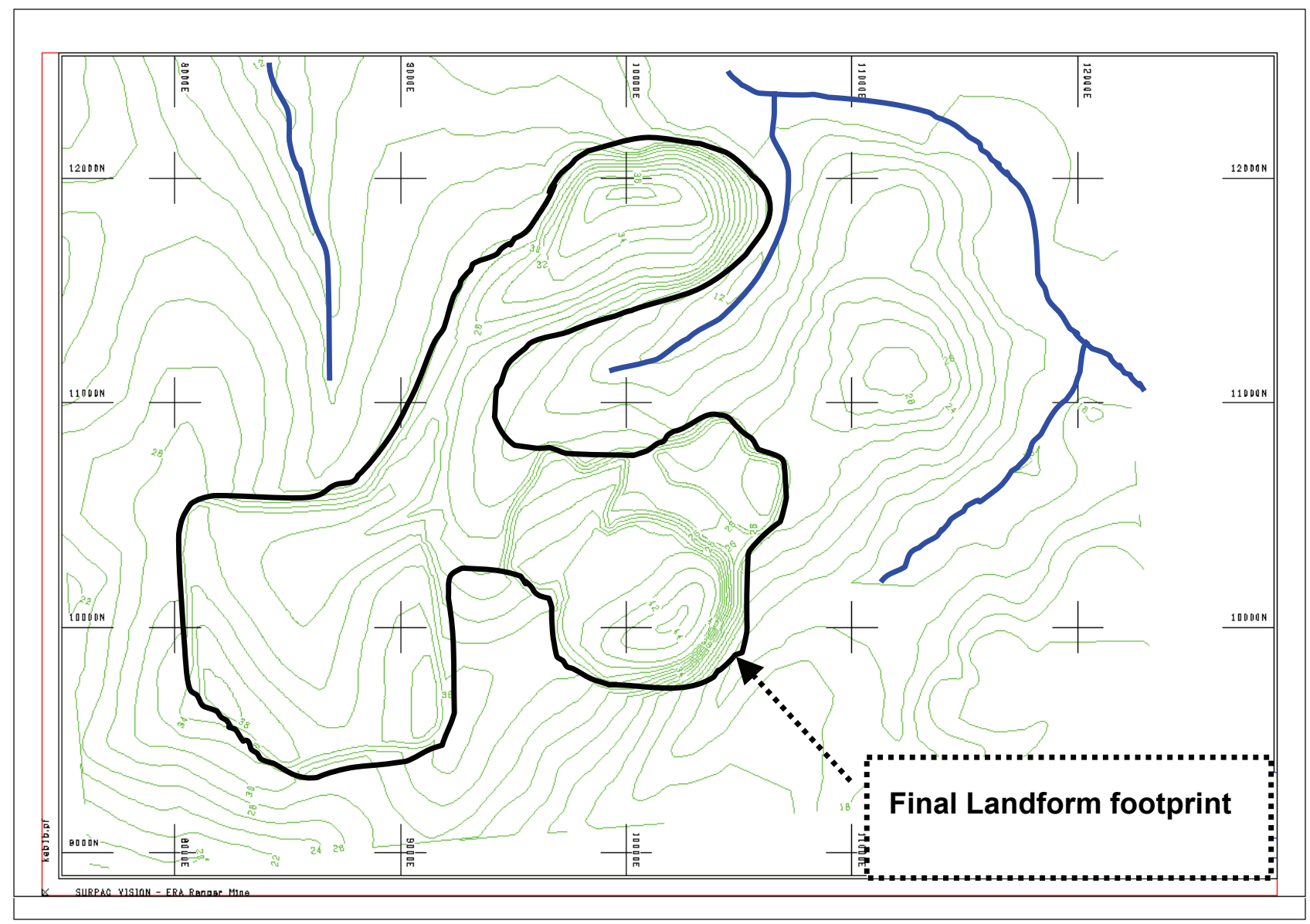

Figure 6 Draft final landform design

\subsection{Environmental Evaluation}

\subsubsection{Ecosystem support}

Water balance processes, particularly the capacity of the waste rock landform to provide sufficient soil water storage to supply the woodland evapotranspiration requirement is seen as a key component of evaluating environmental support. Initial modelling of possible soil and vegetation covers for the rehabilitation of the Ranger Uranium Mine, Northern Territory, was done using the WEC-C model (Croton \& Barry, 2001). The WEC-C model has been used extensively in the south-west of Western Australia for the study of man's effects on the water balance, particularly in terms of bauxite mining, forestry and agriculture (e.g. Croton \& Bari, 2001).

Table 4 shows the results of 1D simulation. The first phase of the WEC-C modelling employed a simple 1D vertical profile of what was considered to be the typical rehabilitation profile. Starting from the soil surface the layering was: a metre thick cover layer, a metre thick clay layer, three metres of waste rock, and seven metres of subsoil. Table 4 shows the results of the 1D simulation with varying Leaf Area Index (LAI) for the vegetation and varying hydraulic conductivity $\left(\mathrm{K}_{\text {sat }}\right)$ for the clay liner. Three items have been reported: average runoff, groundwater recharge (water discharging in the model via the drainage layer under the subsoil), and transpiration ratio (which is the ratio of simulated transpiration following accounting for soil water availability to potential transpiration; when the transpiration ratio is 1.0 there is no water stress, when it is less than 1.0 where is water stress). 
Average runoff, groundwater recharge and transpiration ratio for the 1D model for the cases studied

\begin{tabular}{|c|c|c|c|c|}
\hline \multicolumn{5}{|c|}{ Runoff (\% rainfall) } \\
\hline & \multicolumn{4}{|c|}{$\mathrm{K}_{\text {sat }}$ Clay (mm/day) } \\
\hline LAI & 5 & 10 (base) & 20 & 40 \\
\hline $0.4-0.8$ & 10 & 7 & 6 & 6 \\
\hline $0.6-1.2$ & 9 & 7 & 6 & 6 \\
\hline $0.8-1.6$ (base) & 8 & 6 & 6 & 6 \\
\hline $1.0-2.0$ & 8 & 6 & 6 & 6 \\
\hline \multicolumn{5}{|c|}{ Groundwater recharge (\% rainfall) } \\
\hline & \multicolumn{4}{|c|}{$\mathrm{K}_{\text {sat }}$ Clay (mm/day) } \\
\hline LAI & 5 & 10 (base) & 20 & 40 \\
\hline $0.4-0.8$ & 20 & 24 & 25 & 25 \\
\hline $0.6-1.2$ & 12 & 15 & 16 & 16 \\
\hline $0.8-1.6$ (base) & 6 & 8 & 9 & 9 \\
\hline $1.0-2.0$ & 3 & 5 & 6 & 6 \\
\hline \multicolumn{5}{|c|}{ Transpiration ratio } \\
\hline & \multicolumn{4}{|c|}{$\mathrm{K}_{\text {sat }}$ Clay (mm/day) } \\
\hline LAI & 5 & 10 (base) & 20 & 40 \\
\hline $0.4-0.8$ & 1.00 & 1.00 & 1.00 & 1.00 \\
\hline $0.6-1.2$ & 1.00 & 1.00 & 1.00 & 1.00 \\
\hline $0.8-1.6$ (base) & 0.96 & 0.96 & 0.96 & 0.96 \\
\hline $1.0-2.0$ & 0.84 & 0.85 & 0.85 & 0.85 \\
\hline
\end{tabular}

In Table 4 the base case scenarios is a $\mathrm{K}_{\text {sat }}$ of $10 \mathrm{~mm} /$ day for the clay layer, and vegetation described by the LAI case $0.8-1.6$ have been flagged. In terms of runoff, the variation between the cases in Table 4 is small, in the range 6 to $10 \%$ of rainfall; because for these $1 \mathrm{D}$ cases the control to runoff is a combination of the hydraulic conductivities of both the capping and the clay liner, and the water holding capacities of these layers. As the variation in hydraulic conductivity for the clay liner given in Table 4 affects only one of these four factors, the variation in runoff isn't large. For recharge, the range of values is larger, 3 to $25 \%$; because both LAI and soil conductivity are controls for groundwater recharge as, in essence, recharge is the water which can escape use by the vegetation on its passage through the profile.

The key findings from the modelling were that the water balance of the final rehabilitation will be highly dependent on the soil profile, in terms of soil layering and the soil-water characteristics of the soil layers, and the density of the final vegetation. In terms of analogues, there is the need to restore the water balance as close as possible to that of the natural system in the Ranger area. This objective leads to the hydrology and water balance study programme schematically outlined in Figure 7. In Figure 7 there is a logical progression from base monitoring and studies on the left hand side, through modelling and other design inputs in the centre, to the deliverables on the right hand side. In particular, the base monitoring includes a control catchment that contains the vegetation analogue area, and a mine revegetation catchment. To complement this base monitoring, there will be supporting studies to define the soils and vegetation of natural environment and those that are likely to exist following mine rehabilitation. 


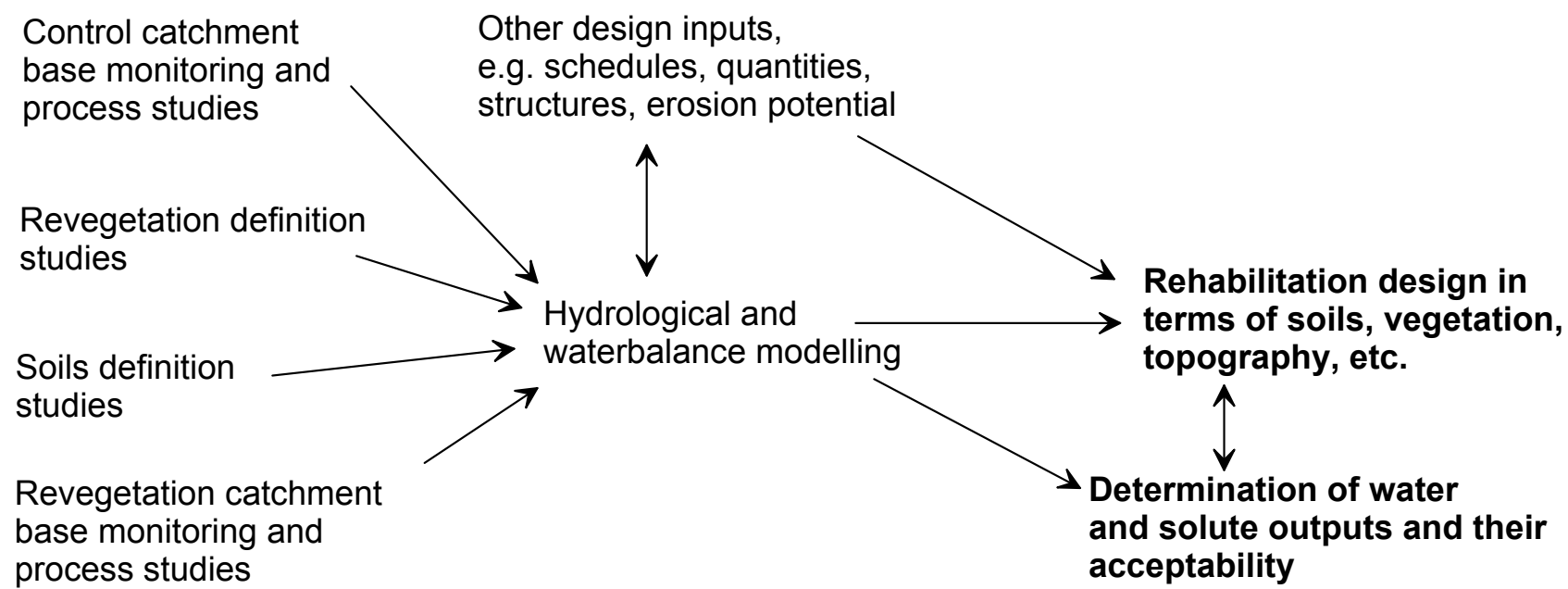

Figure $7 \quad$ Schematic of the principle components of the hydrological and water balance studies for Ranger Mine rehabilitation

\subsubsection{Radiation}

It is a primary requirement for closure that residual radiation at the site does not present a health or environmental risk. Placement and containment of mineralised material in the mined out pits is the core design approach to ensure that this requirement is achieved. In terms of cover design, the radiation monitoring carried out by the mine has shown that a cover of "clean waste" rock one metre thick or reduces the radon flux emissions and total radiation count rates from mineralised waste rock and tailings to that of the cover material.

\subsubsection{Landscape stability}

Once a design for a landform has been produced, predictive modelling using the SIBERIA landform evolution model (LEM) (Hancock, 2004) is used to evaluate landform stability and assess catchment impact. Typical output from SIBERIA showing elevation changes over a 1000 year modelling period are shown in Figure 8. Cover integrity performance and the need for more detailed design can be assessed from this. Further assessment of erosion impacts from the landform on sediment delivery to the receiving streams will be made using the methods developed in Evans (2000). Environmental impact is then assessed in terms of relative increase in estimated sediment concentration above background. This integrated assessment of landform stability issues and environmental implications guides discussion and revision of detailed design options with stakeholders. 


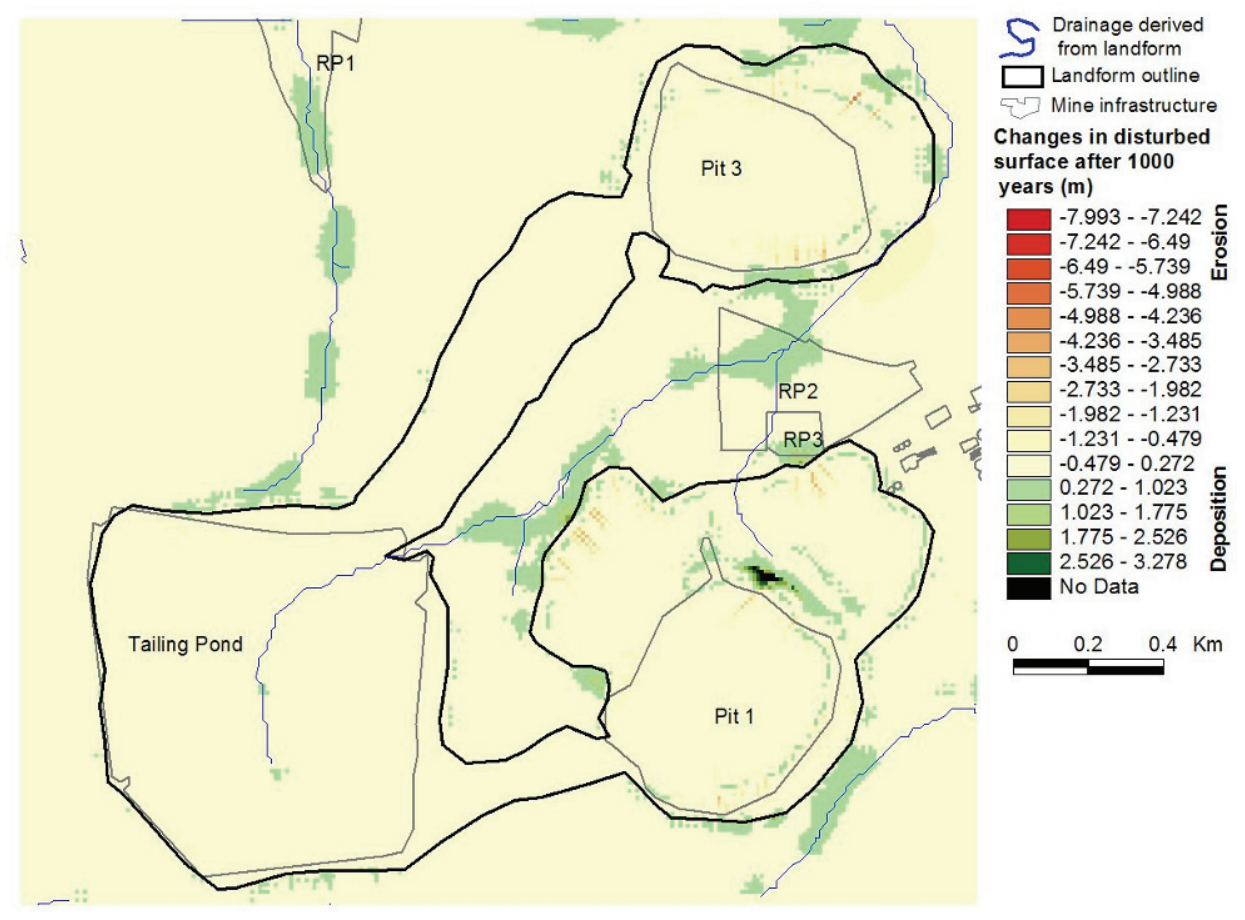

Figure 8 Simulated changes, using SIBERIA, in a revegetated surface over 1000 yrs

\subsubsection{Seepage}

The waste rock materials consist of largely of chloritised schists and carbonates which are weathered to varying degrees. The chloritised schists contain varying amounts of finely divided sulfides (pyrite) dispersed through the rock structure. The pattern in water chemistry is dominated by the magnesium and sulfate produced from chlorite and sulfide weathering and $\mathrm{pH}$ is balanced by alkalinity produced from the weathering of carbonate minerals. Based on the trends in Electrical Conductivity (EC) and $\mathrm{pH}$ from operational monitoring of clean waste rock (1's material) we envisage that an active seepage management system will be required for approximately ten years after closure, after which greater reliance will be put on a passive system of wetland basins to provide the required control over water quality impacts on the receiving environment.

\subsubsection{Traditional land use values}

The Ranger Mine Area is in close proximity to highly significant aboriginal sites in the escarpment immediately to the east of Pit 1 and the Magela Floodplain to the west. The area is used for traditional hunting and food collection. As a consequence of this, the rehabilitated mine site needs to be in context with the surrounding natural landscape with regard to water bodies, surface relief and aspects of the surface cover (such as rockiness, and radiation dose). The Traditional Owners have consulted with ERA on two occasions with respect to landform. In the first instance in 2002 the consultation focussed on developing a common vision for the rehabilitated landscape. This was done by visiting a natural analogue similar in size and shape to a rehabilitated mine site. The second consultation in 2005 focussed on Traditional Owner recommendations regarding surface cover and revegetation that would support land use after closure of the mine. Feedback from this consultation is guiding order of magnitude assessment of closure planning options that ERA is currently making. This analysis feeds into an overall closure plan for the Ranger operation. Further consultation is at the request of the Traditional Owners. However, the context will be driven by changes to the mine plan and developing strategic and adaptive management programs that can ensure acceptable revegetation and cover construction outcomes. 


\section{CONCLUSIONS}

We have described an iterative process that uses our understanding of the natural, or analogue, environment to develop a landform and vegetation design for closure at ERA Ranger mine. The landform design is built around a pit backfill strategy to contain mineralised material and produce an acceptable landscape. While remnant stockpile reshaping and cover construction needs to be implemented in ways that support local woodland ecosystems and create a water balance close to the natural system. Further refinement of the approach is envisaged before the planned end of mining in 2008. Work that further defines cover specifications to create ambient levels of environmental processes, and development of cover construction methods that will meet specification is required.

Traditional Owners of the site have a guiding role in determining whether landform construction plans are acceptable. Direct consultation with Traditional Owners has focussed the vision for the post-mining landscape and provided timely advice to the assessment of major closure options. Further consultation is an integral part of an iterative approach. Using analogous landforms and ecosystems will provide the context that underpins communication on design and construction issues as they arise.

\section{ACKNOWLEDGEMENTS}

This work has relied on the continued support of ERA Ranger mine and the stakeholder community. In particular, the traditional owners and eriss. John Millbank, Senior Mining Engineer formerly of the ERA Mine Department provided the mine plan and stockpiling plan estimates and landform design. Jeff Archer, Manager Mining at ERA provided the support for the closure planning process presented here.

\section{REFERENCES}

Cook, P.G. (1998) Water balance of a tropical woodland ecosystem, northern Australia: a combination of micrometeorological, soil physical and groundwater chemical approaches. Journal of Hydrology, 210, pp. 161-177.

Coops, N.C. and Catling, P.C. (2002) Prediction of the spatial distribution and relative abundance of ground-dwelling mammals using remote sensing imagery and simulation models. Landscape Ecology, 17(2), pp. 173-188.

Croton, J.T. and Bari, M.A. (2001) Using WEC-C, a fully distributed, deterministic catchment model to simulate hydrologic responses to agricultural clearing. Environmental Modelling and Software, Vol. 16, pp. 601-14.

Croton, J.T. and Barry, D.A. (2001) WEC-C: A distributed, deterministic catchment model - theory, formulation and testing. Environmental Modelling and Software, Vol. 16, pp. 583-99.

Evans, K.G. (2000) Methods for assessing mine rehabilitation design for erosion impact. Australian Journal of Soil Research, 38, pp. 231-47.

Gallant, J.C. and Wilson, J.P. (1996). TAPES-G: a grid-based terrain analysis program for the environmental sciences. Computers and Geosciences, 22, pp. 713-722.

Hancock, G.R. (2004) The use of landscape evolution models in mining rehabilitation design. Environmental Geology 46, pp. 561-573.

Hancock, G.R., Loch, R.J. and Willgoose, G.R. (2003) The design of post-mining landscapes using geomorphic principles. Earth Surface Processes and Landforms 28, pp. 1097-1110.

Hollingsworth, I.D. and Lowry, J. (2005) Landscape reconstruction at Ranger mine. In Proceedings of the North Australian Remote Sensing and GIS Conference, Darwin, 4-7 July 2005, Applications in Tropical Spatial Science (CD-ROM).

Mackey, B.G., Mullen, I.C., Baldwin, K.A., Gallant, J.C., Sims, R.A. and McKenney, D.W. (2000) Towards a Spatial Model of Boreal Forest Ecosystems: The Role of Digital Terrain Analysis. Terrain Analysis Principles and Applications, J.P. Wilson and J.C. Gallant (eds), John Wiley \& Sons, Brisbane, pp. 391-422.

McGarigal, K., Marks, B.J. (1994) FRAGSTATS: Spatial Pattern Analysis Program for Quantifying Landscape Structure. In. (Forest Science Department, Oregon State University: Corvallis)

Moore, I.D., Norton, T.W. and Williams, J.E. (1993). Modeling environmental heterogeneity in forested landscapes. Journal of Hydrology, 150, pp. 717-747. 
Nanson, G.C., East, T.J. and Roberts, R.G. (1993) Quaternary stratigraphy, geochronology and evolution of the Magela Creek catchment in the monsoon tropics of northern Australia. Sedimentary Geology 83, pp. 277-302.

Nicolau, J.M. (2003) Trends in relief design and construction in opencast mining reclamation. Land Degradation \& Development 14, pp. 215-226. 